\title{
Treponema denticola (ex Brumpt 1925) sp. nov., nom. rev., and Identification of New Spirochete Isolates from Periodontal Pockets
}

\author{
E. C. S. CHAN, ${ }^{1,2 *}$ R. SIBOO,${ }^{2}$ T. KENG,${ }^{2}$ N. PSARRA, ${ }^{1}$ R. HURLEY,,${ }^{1}$ S.-L. CHENG, ${ }^{2}$ \\ AND I. IUGOVAZ ${ }^{1}$ \\ Department of Oral Biology, Faculty of Dentistry, ${ }^{1}$ and Department of Microbiology and Immunology, \\ Faculty of Medicine, ${ }^{2}$ McGill University, Montreal, Quebec, Canada H3A 2B4
}

\begin{abstract}
Standard growth and isolation methods were used to obtain five new treponema strains in pure culture from deep periodontal pockets. The strains were identified to the species level by various methods, including agglutination, immunofluorescence, a dot blot immunoassay, electron microscopy, gas-liquid chromatography of metabolic volatile fatty acids, and DNA hybridization. Two isolates were strains of Treponema socranskii; the other three were strains of "Treponema denticola," a species described in 1925 by Brumpt. Because no type strain was designated for this species previously, the name was not included on the Approved Lists of Bacterial Names and has no current nomenclatural standing. We propose that Treponema denticola (ex Brumpt) sp. nov., nom. rev. is a valid and distinct species of the genus Treponema and designate strain ATCC 35405 as the type strain and strains ATCC 33520 and ATCC 35404 as reference strains. $T$. denticola appears to be the species that is most frequently isolated from periodontal pockets. Unless new isolation and cultivation techniques are introduced, it appears that present technology can yield only isolates belonging to the currently described oral anaerobic spirochete species and that there is little chance of isolating the larger treponemes.
\end{abstract}

The treponemes have been implicated in the etiology of all forms of periodontal disease by virtue of their proliferation to high numbers in diseased sites $(6,13,15)$. Evidence on the quantitative relationship of Treponema denticola to the severity of periodontal disease has been presented previously $(22,23)$. Investigations to elucidate the underlying mechanisms for the virulence of the oral anaerobic treponemes have been performed $(5,7,18,21,27)$. Not only has $T$. denticola been the spirochete species of choice for laboratory investigations as described above, but it is also the species that is most frequently isolated from subgingival plaque $(4,20)$.

The species name $T$. denticola is not on the 1980 Approved Lists of Bacterial Names (24) or on any subsequent validation list. Therefore, this name has not been validly published. However, it has been published in Bergey's Manual of Systematic Bacteriology (25), this is only "effective publication" according to the International Code of Nomenclature of Bacteria (11), and a type strain was not designated. In this study, we characterized five new oral anaerobic spirochetes isolated from periodontal pockets and identified them to species level. On the basis of our data, as well as the previously documented characteristics of the taxon, we propose that Treponema denticola (ex Brumpt 1925) sp. nov., nom. rev. (2) is a valid and distinct species of the genus Treponema and designate strain ATCC 35405 as the type strain and strains ATCC 33520 and ATCC 35404 as reference strains.

\section{MATERIALS AND METHODS}

Isolation of new spirochetes. Treponemes are usually isolated by the following two general methods: (i) membrane filters placed on the surface of agar media and (ii) incorporation of the antibiotic rifampin into media as a selective

\footnotetext{
* Corresponding author.
}

agent (25). In our attempt to isolate new oral anaerobic spirochetes, we combined these two methods (3) and used membrane filters of several pore sizes $(1.2,3$, and $5 \mu \mathrm{m})$ and rifampin at a final concentration of $4 \mu \mathrm{g} / \mathrm{ml}$. Several spirochete media were compared for their ability to support growth of $T$. denticola (data not shown), new oral spirochete (NOS) medium of Leschine and Canale-Parola (12) was the medium of choice and was used throughout this work. Treponemes migrated through the filters and grew in NOS agar as a white, hazy, cottony growth. Such growth was removed with a Pasteur pipette and was inoculated into prereduced NOS agar medium containing rifampin. The resulting growth was checked by dark-field microscopy for purity.

Five axenic cultures were isolated as described above and were designated strains 975a, 975b, 9710, 9715, and 979.

Control spirochete cultures. The following spirochete cultures were used for comparison: $T$. denticola ATCC $35405^{\mathrm{T}}$ (serotype or strain $\mathrm{a}^{\mathrm{T}}$ ) $(\mathrm{T}=$ type strain), ATCC 35404 (strain c), strain d (4), and ATCC 33520; Treponema vincentii ATCC 35580; Treponema socranskii subsp. socranskii ATCC 35536; and Treponema phagedenis Reiter. T. denticola serotypes a, c, and d were isolated and characterized in our laboratory (3). All cultures, including the new isolates, were maintained on NOS medium containing $0.3 \%$ agar; cells for study were grown in NOS broth.

Agglutination tests. Cells of each isolate were sedimented by centrifugation at $8,000 \times g$ for $10 \mathrm{~min}$ at $4^{\circ} \mathrm{C}$. They were then washed twice with $0.01 \mathrm{M}$ phosphate-buffered saline (pH 7.2). Suspensions containing washed cells of the isolates were standardized to an optical density at $490 \mathrm{~nm}$ of 1.0 . The rabbit antisera used for testing were prepared as described previously (4). We used antisera to the following spirochetes: T. vincentii ATCC 35580, T. socranskii ATCC 35536, T. phagedenis Reiter, and T. denticola ATCC $35405^{\mathrm{T}}$ (serotype a), ATCC 35404 (serotype c), and serotype d. These antisera were serially diluted twofold in $10 \mathrm{mM}$ Tris buffer (pH 7.2) containing $1 \%$ bovine serum albumin and $0.05 \%$ 
TABLE 1. Results of agglutination tests performed with oral spirochete isolates

\begin{tabular}{|c|c|c|c|c|c|c|}
\hline \multirow[b]{2}{*}{ Strain } & \multicolumn{6}{|c|}{ Highest titer of rabbit antiserum prepared against ${ }^{a}$ : } \\
\hline & $\begin{array}{c}\text { T. denticola } \\
\text { ATCC } 35405^{\mathrm{T}}\end{array}$ & $\begin{array}{l}\text { T. denticola } \\
\text { ATCC } 35404\end{array}$ & $\begin{array}{l}\text { T. denticola } \\
\text { strain d }\end{array}$ & $\begin{array}{l}\text { T. socranskii } \\
\text { ATCC } 35536\end{array}$ & $\begin{array}{c}\text { T. vincentii } \\
\text { ATCC } 35580\end{array}$ & $\begin{array}{l}\text { T. phagedenis } \\
\text { Reiter }\end{array}$ \\
\hline $975 \mathrm{a}$ & 0 & 0 & 0 & 32 & 0 & 16 \\
\hline $975 b$ & 0 & 0 & 0 & 4 & 0 & 16 \\
\hline 9710 & 8 & 16 & 8 & 16 & 2 & 8 \\
\hline 9715 & 8 & 16 & 8 & 32 & 0 & 8 \\
\hline 979 & 8 & 32 & 8 & 0 & 8 & 8 \\
\hline Homologous strain & 64 & 64 & 128 & 128 & 32 & 32 \\
\hline
\end{tabular}

${ }^{a}$ Reciprocal of the highest dilution that produced positive slide agglutination.

Tween 20 (TBT buffer). Portions $(10 \mu \mathrm{l})$ of each dilution of a test antiserum (e.g., anti- $T$. vincentii antiserum) were placed onto different slides, and $10 \mu \mathrm{l}$ of a cell suspension of a single isolate was added to each of the diluted antiserum preparations. This procedure was repeated with each of the isolates. The cells and antiserum were mixed, and the reaction was scored visually by eye. The reciprocal of the highest dilution that gave positive agglutination was considered the highest titer. Each test antiserum interacting with its homologous cell suspension (e.g., $T$. vincentii and anti- $T$. vincentii antiserum) was used as a positive control, and serially diluted normal rabbit serum was used as the negative control.

Indirect immunofluorescence. Cell suspensions of each isolate were standardized as described above. Portions (10 $\mu$ l) of a cell suspension of one of the isolates were placed onto six microscopic slides, and the resulting smears were allowed to air dry. The smears were heat fixed and rehydrated with TBT buffer for $15 \mathrm{~min}$, and the TBT buffer was drained off the slides. All of the test antisera were diluted 1:20 in TBT buffer, and $20 \mu$ l of each diluted antiserum (e.g., anti- $T$. vincentii or anti- $T$. socranskii antiserum) was added to a smear. The slides were incubated for $20 \mathrm{~min}$ at room temperature, after which they were washed three times with TBT buffer and then drained dry. A $20-\mu l$ portion of a 1:20 dilution of fluorescein-conjugated goat anti-rabbit immunoglobulin G in TBT buffer was added to each smear, and the slides were incubated for $20 \mathrm{~min}$ at room temperature. The smears were washed three times with TBT buffer and once with distilled water. The water was drained from each slide, and 1 drop of mounting fluid $(90 \%$ glycerol, $10 \%$ carbonate buffer; $\mathrm{pH}$ 9.0) was placed onto each smear, which was then covered with a coverslip. The coverslips were sealed to the slides with nail varnish. The smears were examined by performing epifluorescence microscopy with a Leitz Dialux microscope at a magnification of $\times 1,000$. This procedure was repeated with each of the isolates. Each test antiserum interaction with the homologous organism (e.g., anti-T. vincentii antiserum and $T$. vincentii) was used as a positive control. Smears of the new isolates or previously characterized oral spirochetes that were treated only with fluoresceinconjugated goat anti-rabbit immunoglobulin $\mathrm{G}$ were used as the negative controls.

Dot blot immunoassay. A dot blot apparatus and nitrocellulose membranes were obtained from Bio-Rad Laboratories, Richmond, Calif. A nitrocellulose membrane was soaked in $10 \mathrm{mM}$ Tris-buffered saline ( $\mathrm{pH} \mathrm{7.2)} \mathrm{for} 20 \mathrm{~min}$ before it was placed into the apparatus.

Blocking solution TBT buffer was applied to each well and allowed to drain by gravity filtration. A $25-\mu l$ portion of cells of an isolate (optical density at $620 \mathrm{~nm}, 0.2$ ) was then added to each well and allowed to settle by gravity filtration. Bovine serum albumin blocking solution $(100 \mu \mathrm{l})$ was added, and after this solution was drained from the apparatus, three washes were done, each with $200 \mu \mathrm{l}$ of $10 \mathrm{mM}$ Tris buffer (pH 7.2) containing $0.05 \%$ Tween 20 (TT buffer) with a vacuum applied. Starting with antiserum diluted 1:80, twofold sequential dilutions were made in TBT buffer (e.g., anti- $T$. vincentii antiserum). Portions $(30-\mu \mathrm{l})$ of each dilution of the specific antiserum (e.g., anti- $T$. vincentii antiserum) were added to different wells. After the antibody solution had drained completely, the preparations were washed three times with TT buffer with a gentle vacuum. A $30-\mu l$ portion of a 1:1,000 dilution of goat anti-rabbit immunoglobulin $G$ alkaline phosphatase was added to each well, and filtration was carried out by gravity. The reaction wells were washed with TT buffer by using a gentle vacuum.

The membrane was then removed and placed into a substrate solution containing $15 \mathrm{mg}$ of 5-bromo-4-chloro-3indoyl phosphate, $30 \mathrm{mg}$ of nitroblue tetrazolium, and $100 \mathrm{ml}$ of $10 \mathrm{mM}$ Tris buffer ( $\mathrm{pH} 9.5$ ). Each of the isolates was tested in the same way with each of the test antisera. The negative control consisted of cells that interacted with the goat anti-rabbit immunoglobulin $\mathrm{G}$ alkaline phosphate conjugate and substrate. The color development solution was

TABLE 2. Indirect immunofluorescence reactions of oral spirochete isolates

\begin{tabular}{|c|c|c|c|c|c|c|}
\hline \multirow[b]{2}{*}{ Strain } & \multicolumn{6}{|c|}{ Reaction with antiserum prepared against ${ }^{a}$ : } \\
\hline & 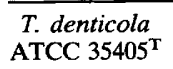 & $\begin{array}{l}\text { T. denticola } \\
\text { ATCC } 35404\end{array}$ & $\begin{array}{l}\text { T. denticola } \\
\text { strain d }\end{array}$ & $\begin{array}{l}\text { T. socranskii } \\
\text { ATCC } 35536\end{array}$ & $\begin{array}{c}T . \text { vincentii } \\
\text { ATCC } 35580\end{array}$ & $\begin{array}{c}\text { T. phagedenis } \\
\text { Reiter }\end{array}$ \\
\hline $975 a$ & 0 & 0 & 0 & +++ & ++ & +++ \\
\hline $975 b$ & 0 & 0 & + & +++ & + & ++ \\
\hline 9710 & + & ++ & ++ & +++ & + & ++ \\
\hline 9715 & + & +++ & + & ++ & ++ & +++ \\
\hline 979 & + & ++ & +++ & ++ & + & ++ \\
\hline Homologous strain & +++ & +++ & $++t+$ & +++ & +++ & +++ \\
\hline
\end{tabular}

${ }^{a}$ The levels of immunofluorescence ranged from ++++ (very strong) to 0 (none). 


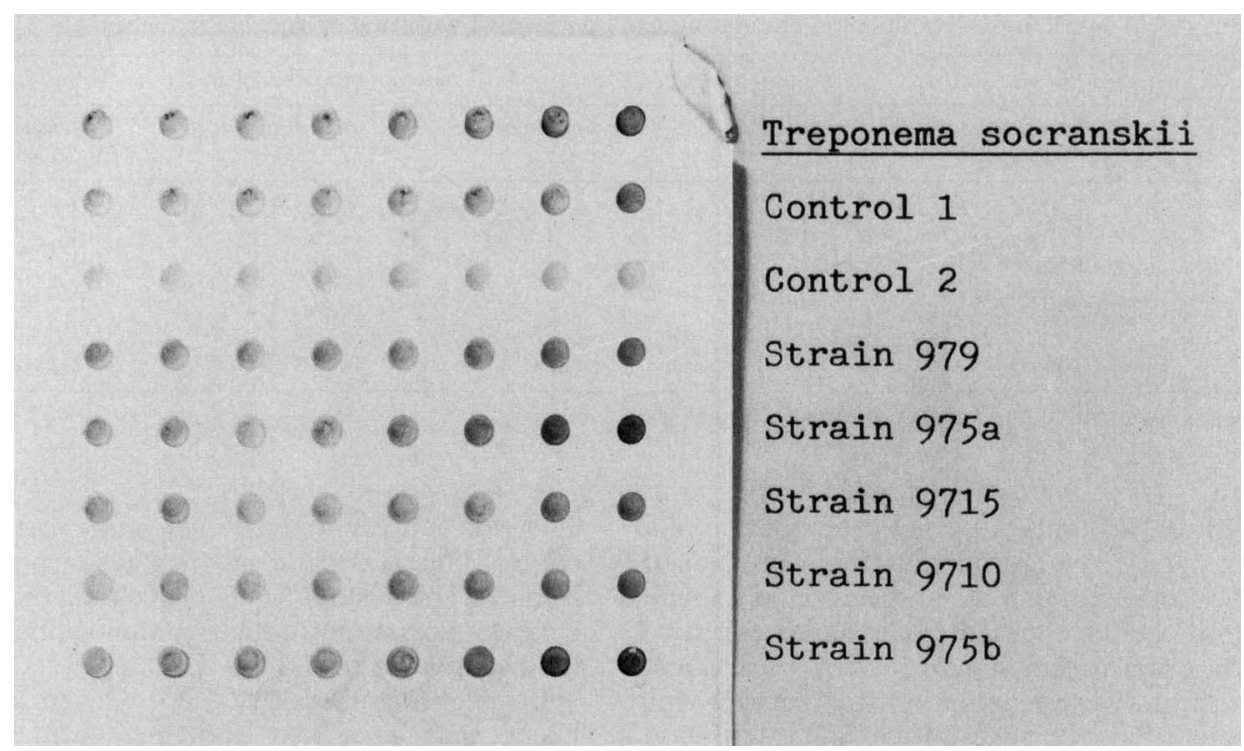

FIG. 1. Dot blot analysis of isolates performed with anti-T. socranskii antiserum. Control 1 was a preparation without anti-T. socranskii antiserum. Control 2 was a preparation without anti-T. socranskii antiserum and cells.

agitated gently for $5 \mathrm{~min}$ in the dark. The nitrocellulose membrane was removed and rinsed with distilled water to stop the reaction.

Electron microscopy. Phosphate-buffered saline-washed cells were suspended in distilled water to an optical density at $620 \mathrm{~nm}$ of 1.0 ; then 1 drop of $2 \%$ phosphotungstic acid stain and 1 drop of cells were mixed together in a petri dish. A copper grid was placed on this mixture. After $15 \mathrm{~s}$ the grid was removed, and the excess liquid was absorbed with a piece of bibulous paper. The negatively stained specimens were examined with a Phillips model 300 electron microscope. The cell length, diameter, wavelength, and amplitude and the number of axial fibrils were determined for each new isolate as described previously (3).

Production of volatile metabolic fatty acids. Cells of the

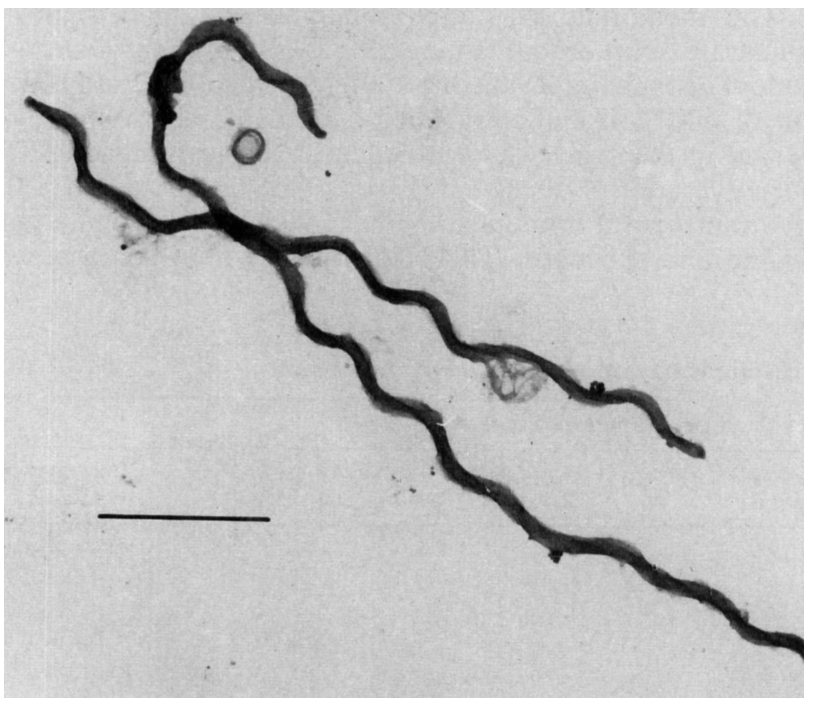

FIG. 2. Whole cells of isolate 9710 used to determine cellular characteristics. Bar $=2 \mu \mathrm{m}$. new spirochete isolates, as well as cells of $T$. denticola strains $\mathrm{a}^{\mathrm{T}}, \mathrm{c}$, and $\mathrm{d}, T$. vincentii, and $T$. socranskii, were grown in NOS broth without supplemental fatty acids. At the end of the exponential growth phase, the cells were centrifuged, and the resulting supernatants were used for an analysis of volatile fatty acids. The procedures used for extraction and determination of the volatile metabolic fatty acids were the procedures of the Anaerobe Laboratory at Virginia Polytechnic Institute and State University (8). A $2.5-\mu 1$ portion of an ether extract was injected into a column (15\% silicone GE SE-52 on Chromosorb W, AW, DMCS; 100/120 mesh; Applied Science Laboratories, Inc., State College, Pa.) for detection. The apparatus used was a Hewlett-Packard model 402 high-efficiency gas chromatograph. Volatile fatty acid standards were obtained from a Capco AnaBac standard solution (International Scientific of Canada, Ottawa, Canada).

DNA homology. Cells of the various strains of spirochetes were harvested by centrifugation $\left(4^{\circ} \mathrm{C}\right)$ and $15,000 \times g$ for 15 min as soon as the cultures reached their maximum density. DNAs were extracted from the cells of all of the strains by using the procedure described by Marmur (16). The DNA concentration obtained for each treponeme strain was determined by measuring $A_{260}$ with a spectrophotometer, using the following relationship: $1.0 \mathrm{U}$ of $A_{260}=50 \mu \mathrm{g}$ of doublestranded DNA per ml.

A $1-\mu \mathrm{g}$ portion of DNA from each known species was denatured by heating it for $10 \mathrm{~min}$ at $95^{\circ} \mathrm{C}$ and then cooling it on ice immediately. Labelling of this DNA with tritiated thymidine 5 '-triphosphate was carried out by using a Random Primed DNA Labelling Kit (catalog no. 1004 760; Molecular Biology Boehringer Mannheim, Mannheim, Germany) or the Random Primers DNA Labeling System (catalog no. 8187SA; Bethesda Research Laboratories, Gaithersburg, Md.) following the instructions of the manufacturers.

Labelled DNA was separated from unincorporated deoxynucleotide triphosphates with Nick columns (catalog no. 17-0855-01; Pharmacia LKB, Biotechnology AB, Uppsala, Sweden), which were used according to the directions of the 


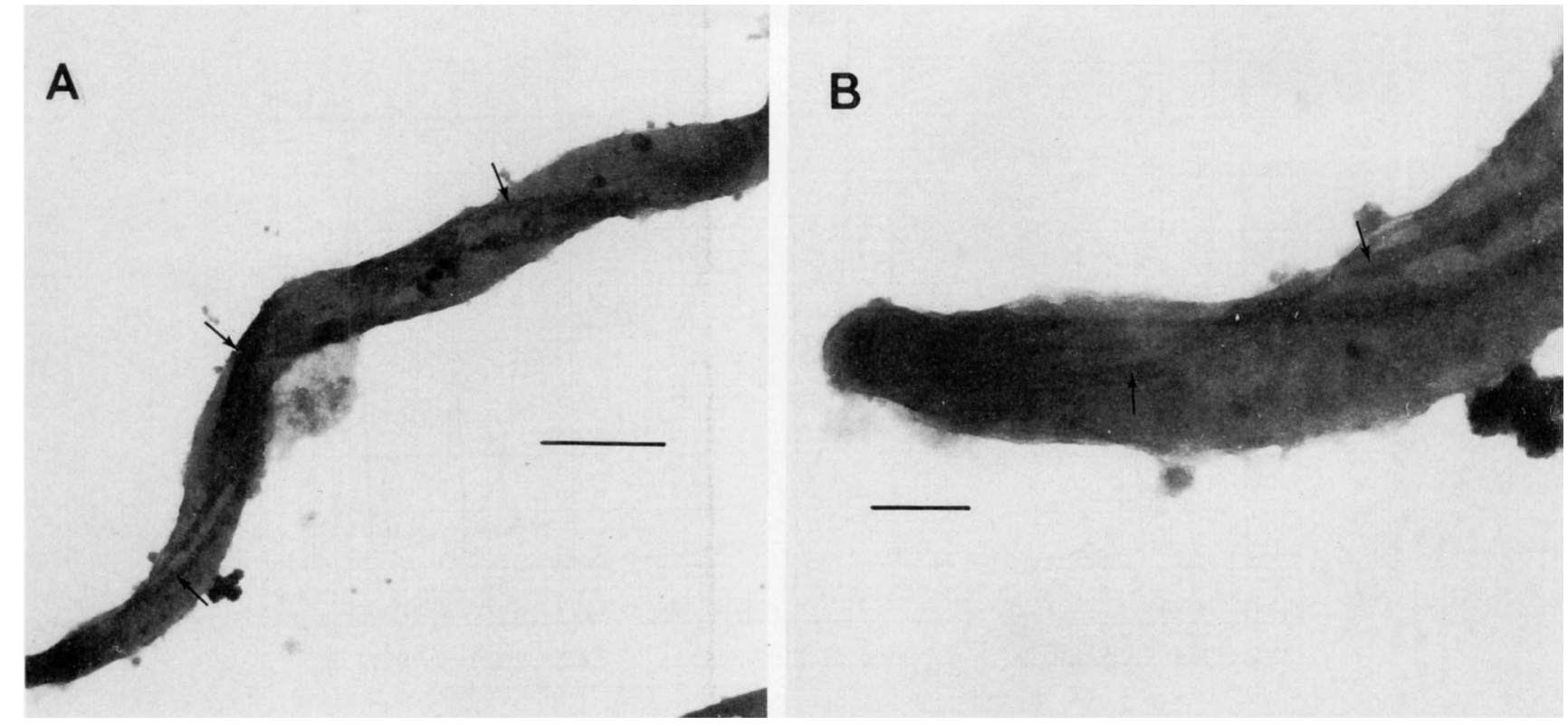

FIG. 3. Isolate 9715 at two magnifications used to determine endoflagellar arrangement. The arrows indicate endoflagella. (A) Bar $=0.5$ $\mu \mathrm{m}$. (B) Bar $=0.1 \mu \mathrm{m}$.

supplier. The labelled DNA was concentrated by ethanol precipitation. The average specific activity of the labelled DNAs was $3.2 \times 10^{6} \mathrm{cpm} / \mu \mathrm{g}$.

DNA hybridization assays were performed as described by Johnson (10). A 30- $\mu$ g portion of unlabelled DNA (or 30 $\mu \mathrm{g}$ of salmon sperm DNA as a control) was mixed with 0.02 to $0.05 \mu \mathrm{g}$ of labelled DNA in a solution containing $0.4 \mathrm{M}$ sodium chloride and $0.4 \mathrm{mM}$ HEPES $(N$-2-hydroxyethylpiperazine- $N^{\prime}$-2-ethanesulfonic acid) buffer ( $\mathrm{pH} 7.0$ ) in a total volume of $120 \mu \mathrm{l}$. The samples were denatured by heating them in a boiling water bath for $10 \mathrm{~min}$ and then incubated at $37^{\circ} \mathrm{C}$ for 20 to $24 \mathrm{~h}$. A $1-\mathrm{ml}$ portion of S1 assay buffer $(5 \mathrm{mM}$ sodium acetate, $0.3 \mathrm{M}$ sodium chloride, $0.5 \mathrm{mM}$ zinc chloride; $\mathrm{pH} 4.6)$ was added to each reaction mixture, and then $225 \mathrm{U}$ of S1 nuclease was added. The reaction mixtures were incubated at $25^{\circ} \mathrm{C}$ for $1 \mathrm{~h}$. A $2-\mathrm{ml}$ portion of ice-cold $10 \%$ (wt/vol) trichloroacetic acid was then added to each sample together with $25 \mu \mathrm{g}$ of carrier DNA. The precipitated DNA was collected on a Whatman glass fiber filter, washed with $10 \%$ trichloroacetic acid, dried, and counted with an LKB model 1215 Rackbeta II liquid scintillation counter. The percentages of homology were calculated as follows: [(counts per minute of hybrid formed with test DNA counts per minute of hybrid formed with salmon sperm DNA)/(counts per minute of hybrid formed with homologous
DNA - counts per minute of hybrid formed with salmon sperm DNA)] $\times 100$.

\section{RESULTS AND DISCUSSION}

Serological tests. Various serological tests were performed to determine whether the new oral anaerobic spirochete isolates had antigenic determinants in common with previously described strains and species of spirochetes.

Table 1 shows the agglutination reactions of the new oral spirochete isolates when they were mixed with rabbit antisera prepared against previously described spirochete strains and species. Strains $975 \mathrm{a}$ and $975 \mathrm{~b}$ did not agglutinate at all with antisera against three strains of $T$. denticola and $T$. vincentii. Strains 9710, 9715, and 979 agglutinated with antisera against $T$. denticola strains $\mathrm{a}^{\mathbf{T}}$, $\mathrm{c}$, and $\mathrm{d}$. In addition, strains 9710 and 9715 agglutinated to quite high titers with antiserum against $T$. socranskii, while strain 979 agglutinated with antiserum against $T$. vincentii but not with antiserum against $T$. socranskii. Of interest was the observation that all of the oral spirochetes cross-agglutinated with antiserum prepared against $T$. phagedenis.

The results of the indirect immunofluorescence reactions for the oral isolates are shown in Table 2. Again, strains 975a and $975 \mathrm{~b}$ did not exhibit any fluorescence with antisera

TABLE 3. Cellular characteristics of new oral spirochete isolates

\begin{tabular}{lcccc}
\hline Isolate & $\begin{array}{c}\text { Cell length } \\
(\mu \mathrm{m})\end{array}$ & $\begin{array}{c}\text { Cell diam } \\
(\mu \mathrm{m})\end{array}$ & $\begin{array}{c}\text { Wavelength } \\
(\mu \mathrm{m})\end{array}$ & $\begin{array}{c}\text { No. of } \\
(\mu \mathrm{m})\end{array}$ \\
\hline $975 \mathrm{a}$ & $5.45 \pm 0.07^{a}$ & $0.15 \pm 0.01$ & $0.71 \pm 0.01$ & $0.30 \pm 0.05$ \\
$975 \mathrm{~b}$ & $6.8 \pm 0.28$ & $0.20 \pm 0.01$ & $0.79 \pm 0.01$ & $0.35 \pm 0.04$ \\
9710 & $9.13 \pm 2.18$ & $0.20 \pm 0.04$ & $0.96 \pm 0.03$ & $0.32 \pm 0.03$ \\
9715 & $7.05 \pm 0.64$ & $0.22 \pm 0.03$ & $1.06 \pm 0.15$ & $0.42 \pm 0.02$ \\
979 & $6.60 \pm 0.26$ & $0.21 \pm 0.04$ & $1.25 \pm 0.28$ & 4 \\
\hline
\end{tabular}

${ }^{a}$ Average \pm standard deviation. Averages were calculated from the data for 5 to 10 cells in negatively stained electron micrographs. 


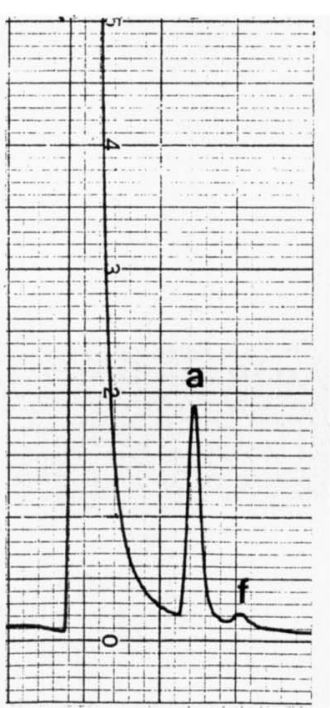

Treponema denticola

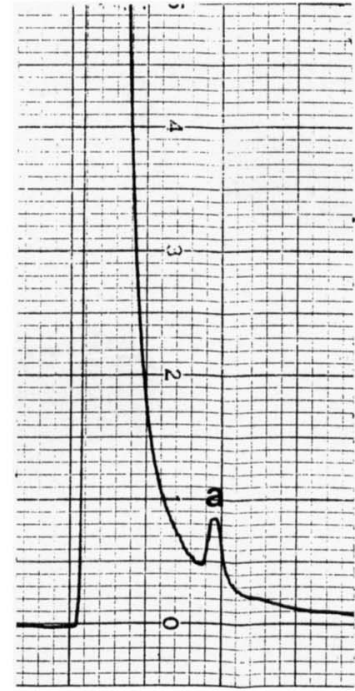

Treponema socranskii

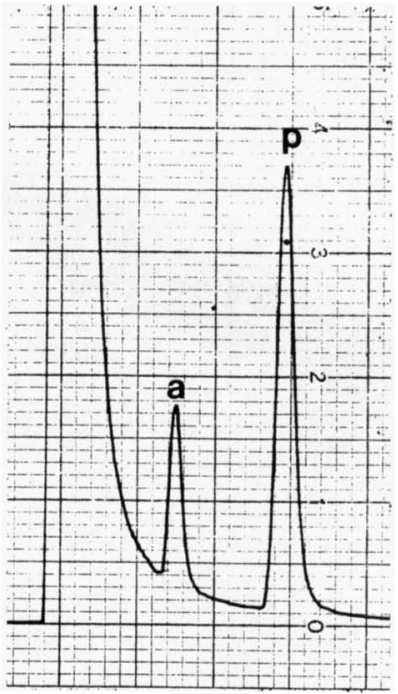

Treponema vincentii

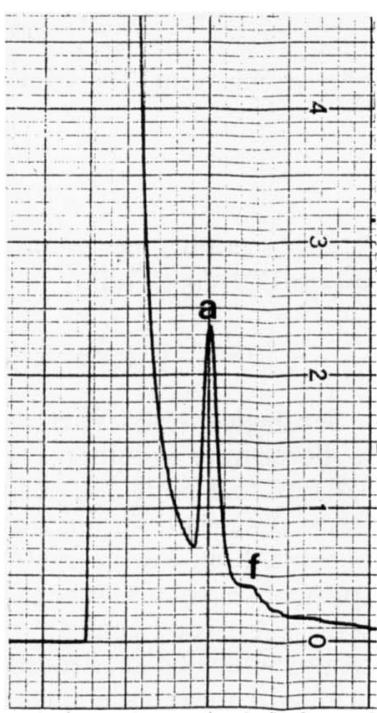

Strain 979

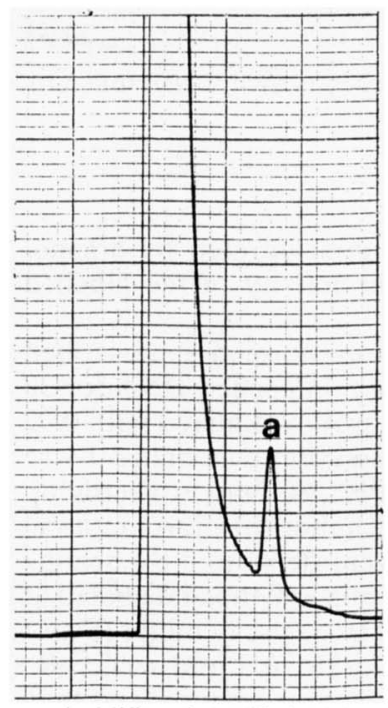

Strain $975 a$

FIG. 4. Volatile fatty acid profiles of known oral treponemas and oral isolates. $T$. denticola produces acetic acid (a) and a trace of formic acid (f); $T$. socranskii produces only acetic acid; and $T$. vincentii produces both acetic acid and propionic acid (p). The volatile fatty acid production profile of isolate 979 is similar to that of $T$. denticola, while the profile of isolate 975a is the same as that of $T$. socranskii.

prepared against the three strains of $T$. denticola, although strain $975 \mathrm{~b}$ showed weak immunofluorescence with antiserum against $T$. denticola strain d. However, both strain $975 \mathrm{a}$ and strain $975 \mathrm{~b}$ showed very strong fluorescence when they were reacted with antiserum against $T$. socranskii. Strains 9710,9715 , and 979 reacted with antisera prepared against all of the previously described spirochetes tested, including $T$. phagedenis.

The dot immunoblotting results obtained when antiserum prepared against $T$. socranskii was used are shown in Fig. 1. A darker blot indicates a positive reaction between the cells and an exposed antiserum. Figure 1 shows that strains 975a and $975 \mathrm{~b}$ cross-reacted with antiserum prepared against $T$. socranskii. The other three strains cross-reacted with antisera prepared against $T$. denticola strains $\mathrm{a}^{\mathrm{T}}$, $\mathrm{c}$, and d (data not shown). The serological results from agglutination, immunofluorescence, and dot blot assays (Tables 1 and 2 and
Fig. 1) show quite clearly that isolates $975 \mathrm{a}$ and $975 \mathrm{~b}$ are probably not members of $T$. denticola but may be members of $T$. socranskii. Similarly, isolates 9710,9715 , and 979 may be members of $T$. denticola but certainly are not members of $T$. socranskii. These findings were evident despite some cross-reactions with polyclonal antibodies, especially with polyclonal antibodies against $T$. phagedenis.

Electron microscopy. Figure 2 shows whole cells of isolate 9710 and is typical of the micrographs used for measuring cell dimensions, wavelengths, and amplitudes. Figure 3 shows isolate 9715 at two magnifications as an example of how endoflagellum numbers were determined for each spirochete isolate. Morphological characterization data for the negatively stained new oral spirochetes are shown in Table 3. The cellular wavelengths of isolates $975 \mathrm{a}$ and $975 \mathrm{~b}$ (average, $0.75 \mu \mathrm{m}$ ) are shorter than the cellular wavelengths of isolates 9710,9715 , and 979 (average, $1.09 \mu \mathrm{m}$ ). Isolates 975a 
TABLE 4. Levels of homology among Treponema strains and new oral spirochete isolates

\begin{tabular}{|c|c|c|c|}
\hline \multirow[b]{2}{*}{ Strain } & \multicolumn{3}{|c|}{ \% Homology with labelled DNA from: } \\
\hline & $\begin{array}{l}\text { T. denticola } \\
\text { ATCC } 33520\end{array}$ & $\begin{array}{l}\text { T. socranskii } \\
\text { ATCC } 35536\end{array}$ & $\begin{array}{c}\text { T. vincentii } \\
\text { ATCC } 35580\end{array}$ \\
\hline T. denticola ATCC 33520 & 100 & 7 & 2 \\
\hline T. denticola ATCC $35405^{\mathrm{T}}$ & 125 & 0 & 0 \\
\hline T. denticola ATCC 35404 & 66 & 10 & 0 \\
\hline T. vincentii ATCC 35580 & 13 & 27 & 100 \\
\hline T. socranskii ATCC 35536 & 3 & 100 & 0 \\
\hline T. phagedenis Reiter & 0 & 14 & 0 \\
\hline $975 a$ & 3 & 84 & 0 \\
\hline $975 b$ & 5 & 90 & 0 \\
\hline 979 & 101 & 12 & 0 \\
\hline 9710 & 86 & 24 & 8 \\
\hline 9715 & 103 & 17 & 0 \\
\hline
\end{tabular}

and 975b had a 1-2-1 endoflagellum arrangement, while the other three isolates had a 2-4-2 arrangement.

Volatile fatty acids produced. The metabolic volatile fatty acid profiles of previously described oral spirochete species are shown in Fig. 4. As Fig. 4 shows, $T$. denticola produced acetic acid and a relatively small amount of formic acid in spent NOS broth; $T$. socranskii produced only acetic acid; and $T$. vincentii produced acetic acid and propionic acid. Figure 4 also shows the volatile fatty acid profiles of isolates 975a and 979 . Isolate $975 \mathrm{a}$ produced only acetic acid; the profile of isolate 975b was similar (data not shown). Isolate 979 produced acetic acid and a trace of formic acid; this profile was shared by isolates 9710 and 9715 .

DNA homologies. The DNA homology results for the isolates and previously described treponema species are shown in Table 4. Substantial levels of homology were observed when isolates $975 \mathrm{a}$ and $975 \mathrm{~b}$ were compared with $T$. socranskii. Isolates 9710,9715 , and 979 exhibited substantial levels of homology with $T$. denticola ATCC 33520.

Identification of new oral anaerobic spirochete isolates. The accumulated data from the characterization studies of the new oral spirochete isolates showed that isolates 975 a and 975b are strains of $T$. socranskii, while isolates 979,9710 , and 9715 are strains of $T$. denticola. The results of the serological tests supported this conclusion even though the agglutination and immunofluorescence data were not clear because of cross-reactions. It should be noted that antiserum against $T$. phagedenis reacted with all of the oral spirochetes tested in agglutination and immunofluorescence reactions. This species is not an oral spirochete. ( $T$. phagedenis is found in ulcers on human external genitalia, and there has been a report of an isolate from a case of primary syphilis in a human.) Five antigens of $T$. phagedenis cross-reacted with antibodies in syphilitic sera (25). In addition, monoclonal antibody C2-1, which was produced by immunization with Treponema pallidum, cross-reacted with $T$. denticola strains, $T$. vincentii, $T$. pallidum, and $T$. phagedenis, as well as Leptospira and Borrelia strains (19). These findings support the hypothesis that common antigenic determinants are shared by Treponema species. Therefore, it was not unusual that Riviere et al. (19) were able to identify a periopathogen related to $T$. pallidum. It follows that the cross-reactions of anti- $T$. phagedenis antiserum with the oral spirochetes which we observed is not surprising. The results of Paster et al. (17) lend credence to the concept that there are crossreactions on a molecular basis; these authors performed a 16S rRNA sequence analysis of $T$. pallidum, $T$. phagedenis, and $T$. denticola and showed that these species exhibit an average level of interspecies similarity of $89.9 \%$.

Electron microscopic data supported the identification described above to the extent that the cellular wavelengths of isolates $975 \mathrm{a}$ and $975 \mathrm{~b}$ are shorter than the cellular wavelengths of the other three new isolates and isolates $975 \mathrm{a}$ and 975b have a 1-2-1 endoflagellar arrangement. Isolates 979,9710 , and 9715 have a 2-4-2 endoflagellar arrangement, which is the dominant arrangement among $T$. denticola strains $(1,26)$. However, the use of endoflagellar arrangement as a definitive criterion in classification is questionable since widely different flagellar arrangements have been reported for $T$. denticola. For instance, 3-6-3 and 5-10-5 endoflagellar arrangements have been documented for $T$. denticola strains $(3,14)$.

However, the comparative data from the analysis of volatile fatty acids in fermented stale medium for the various oral anaerobic spirochete isolates showed clearly that isolates $975 \mathrm{a}$ and $975 \mathrm{~b}$ are $T$. socranskii strains (which produce only acetic acid), while isolates 9710,9715 , and 979 are $T$. denticola strains (which produce acetic acid and a trace of formic acid).

Proposal of $T$. denticola (ex Brumpt) sp. nov., nom. rev. Research on $T$. denticola has been very active in recent years (see above), and thus this species occupies a place of importance in the field of periodontal microbiology. Therefore, it was very surprising that no type strain has been designated previously for this species and that its name was not included on the Approved Lists of Bacterial Names (24) or any subsequent validation list. Hence, the name $T$. denticola has no current nomenclatural standing. For this reason we propose that Treponema denticola (ex Brumpt) sp. nov., nom. rev. is a valid and distinct species of the genus Treponema and designate strain ATCC 35405 as the type strain and strains ATCC 33520 (9) and ATCC 35404 as reference strains. Some characteristics which differentiate $T$. denticola from other Treponema species that are cultivable and do not ferment carbohydrates are shown in Table 5. These characteristics are described in Bergey's Manual of Systematic Bacteriology (25). Two species that were isolated relatively recently from oral cavities, Treponema pectinovorum and $T$. socranskii, are not included in Table 5 because they were not included in Bergey's Manual. Furthermore, $T$. pectinovorum ferments pectin, polygalacturonic acid, galacturonic acid, and glucuronic acid, and $T$. socranskii ferments glucose. Figure 4 also shows that $T$. denticola produces a trace of formate and no propionate and that $T$. vincentii produces acetate plus propionate but no butyrate.

$T$. denticola is a small to intermediate spirochete (20). Even though a 2-4-2 endoflagellar arrangement is common, $T$. denticola strains with higher numbers of axial filaments have been found $(3,14)$. The additional description of the species given below is from Bergey's Manual (25). The organism moves with a jerky but fairly rapid motion. It grows well in peptone-yeast extract-serum medium under anaerobic conditions. The organism is primarily an amino acid fermenter and does not use the glycolytic pathway as a major source of energy. It grows at a pH range of 6.5 to 8.0 and a temperature range of 30 to $42^{\circ} \mathrm{C}$. The species is found in the oral cavities of humans and chimpanzees, usually in deposits at the junctures between and teeth and gums. The $\mathrm{G}+\mathrm{C}$ content of the DNA is $37-39 \mathrm{~mol} \%$ (as determined by the thermal denaturation method).

The type strain, $T$. denticola ATCC 35405, was first described by Cheng et al. (4) and was called serovar a before it was deposited in the American Type Culture Collection 


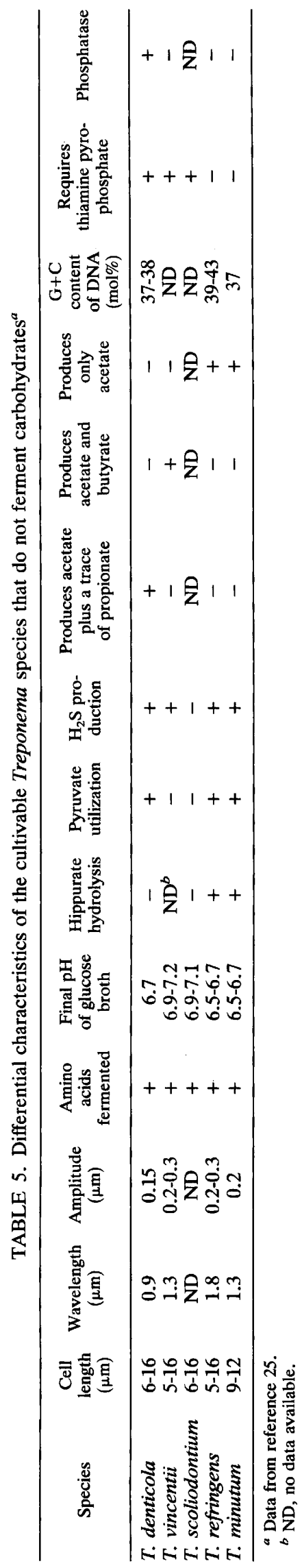

and acquired an accession number. It exhibits $76 \%$ DNA homology with $T$. denticola ATCC 33520 and 82\% DNA homology with $T$. denticola ATCC 35404 , both of which we selected as reference strains. T. denticola ATCC $35405^{\mathrm{T}}$ is susceptible to the antimicrobial agents spiramycin, metronidazole, tetracycline, penicillin G, and streptomycin but is highly resistant to rifampin (the minimum inhibitory concentration is $50 \mu \mathrm{g} / \mathrm{ml}$ ). Its cell dimensions are as follows: length, $7.74 \pm 0.94 \mu \mathrm{m}$; diameter, $0.20 \pm 0.02 \mu \mathrm{m}$; wavelength, $1.23 \pm 0.15 \mu \mathrm{m}$; and amplitude, $0.50 \pm 0.05 \mu \mathrm{m}$. It has 10 axial fibrils and therefore has a 5-10-5 endoflagellar arrangement.

As noted above, $T$. denticola is the oral spirochete species that is isolated most frequently from subgingival plaque. Despite our renewed concerted efforts to isolate new oral spirochete species, the majority of our new isolates were $T$. denticola strains. Unless new isolation and cultivation techniques are developed, it appears that present procedures can yield only isolates belonging to previously described species and that there is little chance of obtaining larger treponemes.

\section{ACKNOWLEDGMENTS}

We thank Noel R. Krieg, Department of Biology, Virginia Polytechnic Institute and State University, Blacksburg, for valuable advice on taxonomy during the writing of the manuscript.

The financial support (grant MA-10509) of the Medical Research Council of Canada is gratefully acknowledged.

\section{REFERENCES}

1. Brondz, I., N.-E. Fiehn, I. Olsen, and M. Sjostrom. 1991. Multivariate analyses of cellular fatty acids and carbohydrates of $1: 2: 1$ and 2:4:2 spirochetes. Acta Pathol. Microbiol. Immunol. Scand. 99:567-575.

2. Brumpt, E. 1925. Les spirochetoses, p. 535-578. In G. H. Roger, F. Widal, and P. J. Tessier (ed.), Noveau traite de medecine. Masson et Cie, Paris.

3. Cheng, S.-L., and E. C. S. Chan. 1983. The routine isolation, growth, and maintenance of the intermediate-size anaerobic oral spirochetes from periodontal pockets. J. Periodontal Res. 18: 362-368.

4. Cheng, S.-L., R. Siboo, T. Chin Quee, J. L. Johnson, W. R. Mayberry, and E. C. S. Chan. 1985. Comparative study of six random oral spirochete isolates. Serological heterogeneity of Treponema denticola. J. Periodontal Res. 20:602-612.

5. Dawson, J. R., and R. P. Ellen. 1990. Tip-oriented adherence of Treponema denticola to fibronectin. Infect. Immun. 58:3924 3928.

6. Gornitsky, M., D. C. Clark, R. Siboo, R. Amsel, I. Iugovaz, C. Wooley, N. Iuliani, and E. C. S. Chan. 1991. Clinical documentation and occurrence of putative periodontopathic bacteria in human immunodeficiency virus-associated periodontal disease. J. Periodontol. 62:576-585.

7. Grenier, D., V.-J. Uitto, and B. C. McBride. 1990. Cellular location of a Treponema denticola chymotrypsinlike protease and importance of the protease in migration through the basement membrane. Infect. Immun. 58:347-351.

8. Holdeman, L. V., E. P. Cato, and W. E. C. Moore (ed.). 1977. Anaerobe laboratory manual, 4th ed. Anaerobe Laboratory, Virginia Polytechnic Institute and State University, Blacksburg.

9. Jacob, E., A. L. Allen, and R. K. Nauman. 1979. Detection of oral anaerobic spirochetes in dental plaque by the indirect fluorescent-antibody technique. J. Clin. Microbiol. 10:934-936.

10. Johnson, J. L. 1981. Genetic characterization, p. 450-472. In P. Gerhardt, R. G. E. Murray, R. N. Costilow, E. W. Nester, W. A. Wood, N. R. Krieg, and G. B. Phillips (ed.), Manual of methods for general bacteriology. American Society for Microbiology, Washington, D.C.

11. LaPage, S. P., P. H. A. Sneath, E. F. Lessel, V. B. D. Skerman, H. P. R. Seeliger, and W. A. Clark (ed.). 1992. International code of nomenclature of bacteria. 1992 Revision. American 
Society for Microbiology, Washington, D.C.

12. Leschine, S. B., and E. Canale-Parola. 1980. Rifampin as a selective agent for isolation of oral spirochetes. J. Clin. Microbiol. 12:792-795.

13. Lindhe, J., B. Liljenberg, and M. Listgarten. 1980. Some microbiological and histopathological features of periodontal disease in man. J. Periodontol. 51:264-269.

14. Loesche, W. J. 1988. The spirochetes, p. 263-271. In M. G. Newman and R. Nisengard (ed.), Oral microbiology and immunology. W. B. Saunders Co., Philadelphia.

15. Loesche, W. J., and B. Laughon. 1982. Role of spirochetes in periodontal disease, p. 62-75. In R. J. Genco and S. E. Mergenhagen (ed.), Host-parasite interactions in periodontal disease. American Society for Microbiology, Washington, D.C.

16. Marmur, J. 1961. A procedure for the isolation of deoxyribonucleic acid from microorganisms. J. Mol. Biol. 3:208-218.

17. Paster, B. J., F. E. Dewhirst, W. G. Weisburg, L. A. Tordoff, G. J. Fraser, R. B. Hespell, T. B. Stanton, L. Zablen, L. Mandelco, and C. R. Woese. 1991. Phylogenetic analysis of the spirochetes. J. Bacteriol. 173:6101-6109.

18. Pietrantonio, F., P. B. Noble, R. Amsel, and E. C. S. Chan. 1988. Locomotory characteristics of Treponema denticola. Can. J. Microbiol. 34:748-752.

19. Riviere, G. R., M. A. Wagoner, S. A. Baker-Zander, K. S. Weisz, D. F. Adams, L. Simonson, and S. A. Lukehart. 1991. Identification of spirochetes related to Treponema pallidum in necrotizing ulcerative gingivitis and chronic periodontitis. $\mathrm{N}$.
Engl. J. Med. 325:539-543.

20. Salvador, S. L., S. A. Syed, and W. J. Loesche. 1987. Comparison of three dispersion procedures for quantitative recovery of cultivable species of subgingival spirochetes. J. Clin. Microbiol. 25:2230-2232.

21. Siboo, R., W. Al-Joburi, M. Gornitsky, and E. C. S. Chan. 1989. Synthesis and secretion of phospholipase $\mathrm{C}$ by oral spirochetes. J. Clin. Microbiol. 27:568-570.

22. Simonson, L. G., C. H. Goodman, J. J. Bial, and H. E. Morton. 1988. Quantitative relationship of Treponema denticola to severity of periodontal disease. Infect. Immun. 56:726-728.

23. Simonson, L. G., C. H. Goodman, and H. E. Morton. 1990. Quantitative immunoassay of Treponema denticola serovar C in adult periodontitis. J. Clin. Microbiol. 28:1493-1496.

24. Skerman, V. B. D., V. McGowan, and P. H. A. Sneath (ed.). 1980. Approved lists of bacterial names. Int. J. Syst. Bacteriol. 30:225-420.

25. Smibert, R. M. 1984. Genus III. Treponema Schaudinn 1905, p. 49-57. In N. R. Krieg and J. G. Holt (ed.), Bergey's manual of systematic bacteriology, vol. 1. The Williams \& Wilkins Co., Baltimore.

26. Tall, B. D., and R. K. Nauman. 1986. Microscopic agglutination and polyacrylamide gel electrophoresis analyses of oral anaerobic spirochetes. J. Clin. Microbiol. 24:282-287.

27. Uitto, V.-J., D. Grenier, E. C. S. Chan, and B. C. McBride. 1988. Isolation of a chymotrypsinlike enzyme from Treponema denticola. Infect. Immun. 56:2717-2722. 